UDC 401.42+415+444.6+808.1

DOI https://doi.org/10.32841/2409-1154.2019.41.1.33

\author{
Syvokin H. V., \\ Candidate of Philological Science, Associate Professor, \\ Department of Foreign Languages \\ Odessa State Academy of Civil Engineering and Architecture
}

\author{
Kartel T.M., \\ Candidate of Pedagogical Science, Associate Professor, \\ Department of Foreign Languages \\ Odessa State Academy of Civil Engineering and Architecture
}

\title{
A TEXT AS A MEANS DEVELOPING ENGLISH SPEECH SKILLS
}

Summary. The work reads about a text as a means developing English speech skills. It has been demonstrated that some specificity of English for special purposes and peculiarities of scientific texts.

The paper is devoted to the problems of teaching professional English to Ukrainian students of technical universities. A text is the main means contributing to the process of efficient teaching the future engineers to communicate the foreign language. Some specificity of English for special purposes and peculiarities of scientific texts are demonstrated.

One of the specific goals of teaching a foreign language at a technical university - understanding and adequate translation of scientific and scientific-technical foreign language texts in the specialt - can be achieved by using authentic language material containing the terminology of the future profession's sublanguage. The structure of the proposed educational scientific texts, the clarity of their pragmatic orientation, and the adequacy of the linguistic tools used play an important role in this case. The right choice of appropriate text-forming elements, which ensure the completeness and integrity of the scientific educational text, is important in small-scale and in limited meaningful educational texts.

The most traditional and common form of presentation of a foreign language is scientific and technical educational texts. Moreover, specially made texts, called "educational", are not exempted from the linguistic features and difficulties inherent in professional texts, and are fully consistent with the studied linguistic phenomena. In this work, the text is understood as a sequence of sentences, words, constructed according to the rules of a given language, this sign system and forming a message.

The text is one of the most complex and interesting objects of research, which allows the possibility of using a variety of approaches, studying its various aspects (morphologicalsyntactic and lexical-semantic, stylistic, pragmatic, cognitive, etc.) in their natural environment. At the same time, the text as a speech structure, possessing semantic and structural coherence, integrity and completeness, acts as a model of monologic and dialogical speech, serves as the basis for constructing independent expression, is an example of a certain style of speech (conversational, scientific, newspaper and journalistic).

Key words: scientific text, means of communication, speech skills, language tools.

Introduction. The paper is devoted to the problems of teaching professional English to Ukrainian students of technical universities. A text is the main means contributing to the process of efficient teaching the future engineers to communicate the foreign language. Some specificity of English for special purposes and peculiarities of scientific texts are demonstrated.

One of the specific goals of teaching a foreign language at a technical university - understanding and adequate translation of scientific and scientific-technical foreign language texts in the specialty [2] - can be achieved by using authentic language material containing the terminology of the future profession's sublanguage. The structure of the proposed educational scientific texts, the clarity of their pragmatic orientation, and the adequacy of the linguistic tools used play an important role in this case. The right choice of appropriate text-forming elements, which ensure the completeness and integrity of the scientific educational text, is important in small-scale and in limited meaningful educational texts.

The most traditional and common form of presentation of a foreign language is scientific and technical educational texts. Moreover, specially made texts, called "educational", are not exempted from the linguistic features and difficulties inherent in professional texts, and are fully consistent with the studied linguistic phenomena. In this work, the text (from lat. Textus fabric, connection) is understood as a sequence of sentences, words (in semantics - signs), constructed according to the rules of a given language, this sign system and forming a message.

The text is one of the most complex and interesting objects of research, which allows the possibility of using a variety of approaches, studying its various aspects (morphologicalsyntactic and lexical-semantic, stylistic, pragmatic, cognitive, etc.) in their natural environment. At the same time, the text as a speech structure, possessing semantic and structural coherence, integrity and completeness, acts as a model of monologic and dialogical speech, serves as the basis for constructing independent expression, is an example of a certain style of speech (conversational, scientific, newspaper and journalistic).

Research Results. Depending on the goals and stage of studying the text at any given moment of training, any one function of the text, its characteristic or a set of text parameters comes to the fore. That is why the principle of appropriateness can be considered the basic principle of selecting texts and working with them, according to which those texts that most closely meet the goals and objectives are included in the educational process.

Based on this principle, the text can be considered as:

1) the unit of representation of the language material;

2) a means of forming speech skills; 
3) a sample of a specific type of message;

4) source of information.

The multifaceted and multifunctional nature of educational texts thematically related to situations of professional communication of texts allows multifaceted teaching of students of higher educational institutions to speak foreign language skills. One of the necessary conditions for effective work on a text in an audience is the creation of a favorable psychological climate, a positive emotional mood [4]. Such an atmosphere helps to reveal different aspects of the student's personality, gives him the opportunity to overcome the emerging psychological barriers (constraint, shyness, self-doubt). Thus, professional English is considered not only as a means of communication, but also as a tool that contributes to the formation of personal characteristics.

The peculiarity of modern training requires the development of the correct skills of both oral and written communication. This requirement imposes additional conditions for the selection and differentiation of the texts studied. That is why, for the purpose of comprehensive training of future specialists in various types of speech activity, students are offered pragmatically diverse educational texts combined thematically (information, description, scientific dispute, report, documentation, instruction). At the same time, the skills of all types of speech activity in a foreign language are worked out: reading, listening, speech (monological and dialogical).

Great attention is paid to the nature of the text used in the classroom by the formulation of specific methodological problems. If the purpose of the work is to teach students logical thinking when working with text, then an important point is the ability to separate the main from the secondary, to build a chain of evidence and arguments in defense of one or another point of view. In the case when the main task is to obtain professional information, the emphasis is on the need to teach students to uniquely decode a written or oral version of a speech work.

Particular attention should be paid to the sources used in the educational process for working out logical thinking, clear phrasing, and the uniqueness of the plan of expression (used language means). To achieve positive results, you can use the texts of scientific, technical, reference books.

Despite the fact that the content and purpose of these types of sources are different, the unifying link is the nature of scientific thinking (operating with concepts and categories, using inferences and reasoning) and the uniformity of speech structures used in them (using formulas, symbols, terms).

Educational and scientific texts can be distinguished into a separate sub-style of the scientific style of presentation, which is characterized by a number of properties: strict standardization of linguistic means, termination, book character of lexical-syntactic structures, an abundance of participial and infinitive constructions, impersonality.

Methodically competent determination of the lesson's target settings provides students with a conscious attitude to the educational process, gives students the opportunity to see the results of their work, and helps to increase learning motivation. The creative way of working on texts involves teaching the student audience techniques to help express their own thoughts, an effective tool in this case is the use of exercises aimed at developing the ability to convince the interlocutor, to argue their opinion [3]. Discussions and scientific debate in this case are the most common didactic techniques. It is advisable to carry out structurally pragmatic means teaching systemically: on the basis of specially designed exercises; through familiarization with abstract samples of scientific and technical literature containing the necessary professional vocabulary; in predicting the course of the narrative and in the selective translation of a selection of excerpts from scientific texts; in the course of creative assignments to students for independent selection of text-forming elements and compilation of a canvas of their own texts based on the materials of their educational, student's scientific or professional activity.

Of particular importance in the learning process is the ability of students to determine the topic - the rheumatic structure of a sentence (utterance) as a structural unit of a written text and oral speech. It is known that the means of pointing out topics and remarks are different in different languages. A number of linguistic means can serve this purpose: grammatical (word order, syntactic constructions and turns), phonetic (intonation), lexical (professionalisms, modal words and particles).

Text coherence is also provided using signal words or guide words, which mean [1]:

a) the beginning of a new thought (to begin with, next, then, at first, first of all, secondly, thirdly);

b) the transition to another subject or the addition of arguments during the presentation of thought (and, and then, besides, in addition to, furthermore, moreover / more than that, also, likewise, again);

c) strengthening arguments with additional considerations (in any case, at any rate, by all means);

d) a generalization of what has been stated and the completion of the presentation of thought (in a word, in brief / in short, on the whole, hence, therefore, so, consequently, finally, to sum up);

e) an explanation of what has already been said (namely, that is to say, in fact, as a matter of fact, in particular, for example, for instance);

f) a paraphrase of what has already been said to explain the content (in other words, to put it in another way);

g) a statement of the opposite thought (but, yet, nevertheless, otherwise, although, though, in spite of, unlike, on the contrary).

Consider some of these text-forming operators. The expressions that determine the relationship between the fragments of the text simultaneously indicate the direction of the train of thought ("by the way", "by the way", "by the way", "besides", etc.) or the emergence of new information. An important place is occupied by priority signals in the logical sequence of the presentation of information, these are words such as "first, second, first of all, further, finally". It should also be borne in mind that the expression "first of all" can be interpreted as a signal of the exceptional communicative significance of a fact, and not as a metatextual warning, the expression "finally" as the most significant final argument, and not a word introducing a final textual remark.

Among the text operators, it is necessary to distinguish those that establish the coherence of the text with the help of signal words: in other words, otherwise speaking, I summarize, for example, that is, I declare, answer, warn. The redundancy of the expressions on this list is obvious. They duplicate the actions that the speaker performs by uttering the subsequent part of the text. The listener (reader) could have noticed that the speaker recalls, emphasizes, repeats, answers. 
No less interesting group in Ukrainian is formed by those verbs whose internal subject is the speaker himself: I protest, agree, deny, etc., in English, respectively, the elliptic forms of "protesting, agreed, contradicting). The specificity of explication of the first person forms of the present tense compared with explications of other persons or of other times, it is explained by its emphatic form and the proactive strengthening of the semantic meaning of the subsequent replica. Of particular interest is the terminology system of educational scientific texts, which includes lexical elements from different fields of knowledge.

Moreover, within the system of a certain sphere of knowledge, each of these terms is unambiguous (monosemantic). It is not easy to distinguish a term from a non-term in the process of language intellectualization, since many of the narrowly professional words turn into well-known and expand their meaning (for example: atom, molecule) and vice versa, when neutral vocabulary narrows its meaning and goes into the professional layer (for example: psychological climate, atmosphere of trust).

Conclusions. The above features of the text can perform a variety of functions: concretization of the logical and semantic relations of the text, combining various elements of the text, communication of text components, emphatic selection of parts of the text. It follows from the above that there is the need for teaching students the skills of isolating language tools that ensure the implementation of these text functions, on the one hand, and the synthesis of several text-forming functions in speech in a foreign language, on the other hand, is obvious.

Teaching students the language techniques of expressiveness of scientific speech is of particular importance for the adequate transmission of the pragmatic orientation of the text in a foreign language. This, as mentioned above, means expressing the movement of thought: the beginning of the presentation, the activation of thought, logical allocation, connection with the foregoing, an indication of the result, connection with the subsequent $[1$, p. 209]. The activation of the above language tools in foreign language communication of students of technical specialties is of particular importance in order to achieve unambiguous, logical sequence of presentation of the content of educational texts.

\section{References:}

1. Валгина Н.С. Теория текста. Москва, 2003. 279 с.

2. Програма $з$ англійської мови для професійного спілкування. / Колектив авторів. Київ : Ленвіт, 2005. 119 с.

3. Тітова В.А. Модульно-проектна методика навчання англійської мови студентів вищих навчальних технічних закладів освіти : автореф. дис. канд. пед. наук: 13.00.04. Київ, 2001.19 с.
4. Prabhu N.S. Second language pedagogy. Oxford : Oxford University Press, 1987. 53 p.

Сивокінь Г. В., Картель Т. М. Навчальний текст як засіб формування англомовних мовних навичок

Анотація. Робота присвячена дослідженню тексту як засобу, що розвиває навички англійської мови. Було продемонстровано певну специфіку англійської мови для спеціальних цілей та особливостей наукових текстів.

Стаття присвячена аналізу проблеми навчання українських студентів технічних університетів професійній англійській мові. Головним засобом успішного навчання майбутніх інженерів основам комунікації англійською мовою є навчальний науковий текст. У роботі розглянуті особливості професійних навчальних текстів, що необхідно враховувати в процесі навчання іноземним мовам.

Одна 3 конкретних цілей викладання іноземної мови в технічному університеті - розуміння і адекватний переклад наукових і науково-технічних іншомовних текстів за фахом - може бути досягнута при використанні автентичного мовного матеріалу, що містить термінологію підмови майбутньої професії. Важливу роль при цьому відіграє структура пропонованих навчальних наукових текстів, чіткість їх прагматичної спрямованості, адекватність лінгвістичних засобів, використаних при цьому. Правильний вибір відповідних текстоутворюючих елементів, які забезпечують завершеність і цілісність наукового навчального тексту, важливий в обмежених за обсягом і інформативно насичених навчальних текстах.

Найбільш традиційною і поширеною формою подачі іноземної мови $€$ науково-технічні навчальні тексти. При цьому спеціально створені тексти, які отримали назву «навчальних», не звільнені від мовних особливостей і труднощів, властивих професійним текстам, і повністю відповідають мовним явищам, які досліджуються. У роботі під текстом розуміється послідовність пропозицій, слів, побудована згідно з правилами певної мови, знакової системи, яка утворює повідомлення.

Текст є одним із найбільш складних і цікавих об'єктів дослідження, який допускає можливість використання різноманітних підходів, вивчення різних його аспектів (морфолого-синтаксичних і лексико-семантичних, стилістичних, прагматичних, когнітивних) в їхньому природному оточенні. У той же час текст як мовна структура, що володіє смисловою і структурною узгодженістю, цілісністю та повнотою, виступає в якості зразка монологічного та діалогічного мовлення, слугує основою для побудови самостійного висловлювання, $є$ прикладом певного стилю мовлення (розмовного, наукового, газетно-публіцистичного).

Ключові слова: науковий текст, засоби комунікації, мовні навички, мовні засоби. 